\title{
拡大・縮小リングを有する円形噴流の数值シミュレーション
}

\section{Numerical Simulation of a Circular Jet with Divergent and Convergent Rings}

\author{
○学 白沢 太一（金沢大院） 正 木綿 隆弘（金沢大） \\ 正 小松 信義（金沢大） 正 木村 繁男（金沢大）
}

\begin{abstract}
Taichi USUZAWA, Graduate School of Natural Sci. and Tech., Kanazawa University, Kakuma-machi, Kanazawa, Ishikawa, 920-1192, Japan

Takahiro KIWATA, School of Mech. Eng., Kanazawa University, Kakuma-machi, Kanazawa, Ishikawa, 920-1192

Nobuyoshi KOMATSU, School of Mech. Eng., Kanazawa University, Kakuma-machi, Kanazawa, Ishikawa, 920-1192

Shigeo KIMURA, Inst. of Nature and Environmental Tech., Kanazawa University, Kakuma-machi, Kanazawa, 920-1192
\end{abstract}

Key Words: Circular Jet, Numerical Simulation, Divergent and Convergent Rings

\section{1. 緒論}

円形噴流は様々な機器に応用されており，その流れを制御 することは機器の性能向上において不可欠である. 円形噴流 を音波などで励起する Active 制御やノズル出口にタブやブ ラフボディを設置することによる Passive 制御の手法 ${ }^{11}$ が試 みられ，噴流制御に関して多くの研究が行われている．本研 究では, 円形噴流の円形ノズル内部に拡大・縮小リングを設 置することで簡易的に速度差が生じる同軸噴流を形成させ， 噴流下流域における混合や拡散制御の可能性を調べる．本報 では，数値シミュレーションにより拡大・縮小リングの形状 が円形噴流の流れ場に及ぼす影響について明らかにする。

2. 数值シミュレーション手法

\section{1 基礎式及び離散化手法}

解析は汎用熱流体ソフトである ANSYS FLUENTを使用し 流れ場を軸対称, 非圧縮, 定常, 粘性流れ, 乱流と仮定した. Navier-Stokes 方程式は対流項を QUICK で，その他の項を 2 次精度中心差分法で離散化した。 また, 圧力と速度のカップ リングとして SIMPLE 法を用いた. 乱流モデルは標準 $k-\varepsilon$ モデルを使用し，乱流エネルギー及び散逸率の輸送方程式は 2 次精度風上差分法で離散化した。

\section{2 解析モデル及び計算条件}

本研究で使用した計算格子を図 1 に示す. 計算領域は半径 方向に $15 D_{\mathrm{o}}$ ，軸方向に $30 D_{\mathrm{o}}$ とし，不等間隔構造格子を用い た。計算格子はノズル壁面の第一格子を $y^{+}<2.5$ とした． $x$ ， $r$ 方向の格子点数はそれぞれ $910 \times 380$ 点で, 総格子点数は約 30 万点である. 流入条件は円形噴流に一様分布 $U_{o}=12 \mathrm{~m} / \mathrm{s}$ を 与え, 乱流境界層を発達させるために拡大・縮小リング上流 に $4 D_{o}$ の助走区間を設けた。作動流体は $15^{\circ} \mathrm{C}$ の空気とした. 計算領域外側はすべり壁条件とし, 出口境界条件を圧力差 $\Delta p=0$ とした. ノズル形状を図 2 に示す. 円形ノズルは直径 $D_{o}$ を $40 \mathrm{~mm}$, 外側ノズル厚さを $2 \mathrm{~mm}$ とした。拡大・縮小リ ングは厚み $b$ を $2 \mathrm{~mm}$, 縮小側リング直径 $D_{\mathrm{c}}$ を $16 \mathrm{~mm}$, 偏向 角度を $6^{\circ}, 12^{\circ}$ とし，リング長さ $L$ を $1 D_{o} ， 2 D_{o}$ とした。レイ ノルズ数 $\operatorname{Re}\left(=U_{0} D_{0} / v, v\right.$ :動粘度 $)$ は $3.3 \times 10^{4}$ となる。

\section{3. 数值シミュレーション結果}

\section{1 拡大・縮小リングが円形噴流に与える影響}

図 3 にリング長さ $L=1 D_{o}$, 偏向角 $\theta=6^{\circ}$ を一例として拡大・ 縮小リングを有する円形噴流の中心軸上の速度分布を示す. 図中には円形噴流の Tollmien の解 ${ }^{2)}$ も示し, 縦軸は中心軸速 度 $u_{c}$ とノズル出口最大速度 $u_{m}$ の比を表す. 噴流下流域にお いて拡大・縮小リングの有無に関わらず，噴流中心軸速度は $x / D_{o}>6$ で減衰し, 拡大リングを有する円形噴流の方が減衰 が早い。速度減衰の傾きは円形噴流において $x / D_{o}$ の-1 乗に 比例するが, 拡大・縮小リングを有する場合, 减開始時は $x / D_{o}$ の-1.25 乗に比例している. また，中心軸上の速度は拡大リ ングの場合に $x / D_{o}=0 \sim 10$ に执いて縮小リングよりも減少す る. 図 4 に拡大・縮小リングの軸方向速度等值線図を示す. 桩大リングの場合にはリング上流から流れてきたノズル内 一様流がリングに衝突してリング前縁から剥離し, 急激に軸 方向速度を増加させる. 増速した流れは, さらにリング壁面 からの剥離による再循環領域の圧力低下によって半径方向 に引き伸ばされて急激に軸方向速度を减少させる. そのため

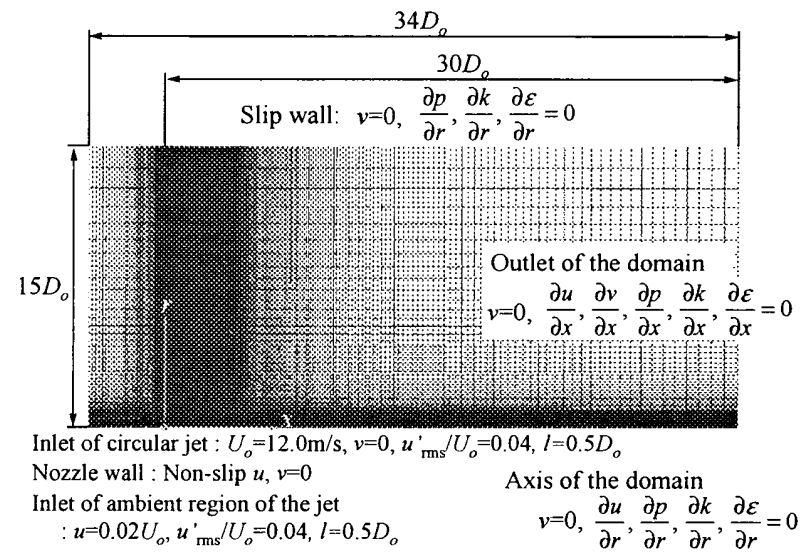

Fig.1 Computational domain and boundary conditions

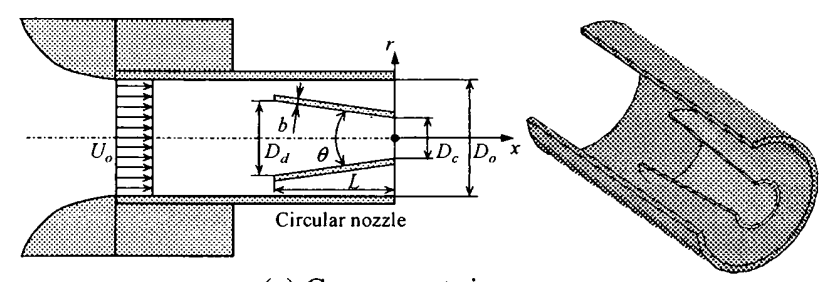

(a) Convergent ring

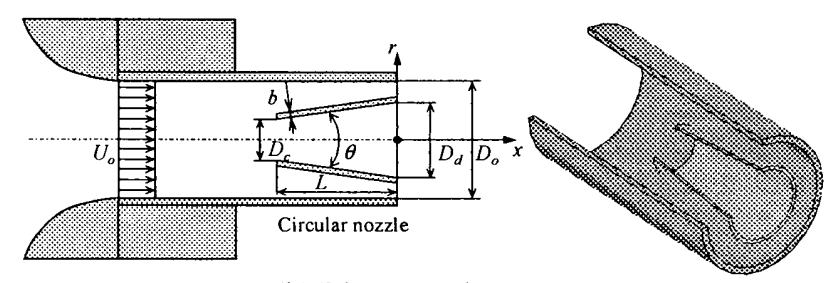

(b) Divergent ring

Fig.2 Schematic diagram of circular nozzles 
拡大リングでは噴流中心軸付近の軸方向速度は減少する.

図 5 に拡大・縮小リング $\left(L=1 D_{o}, \theta=6^{\circ}\right)$ を有する円形噴 流における軸方向速度と軸方向乱れ強さの分布を示す．図 5 (a)の速度分布を見ると, 縮小リングを有する円形噴流の方 が内側噴流の速度が若千大きくなっている.しかし, リング 肉厚と角度の影響による速度欠損が $r / D_{o}=0.25$ 付近に生じる が，この速度欠損は桩大リングを有する円形噴流の方が大き く，その位置も外側にある。そして，この速度欠損は内側混 合領域の下流域まで残っており，結果的に図 3 の中心軸上の 速度変化で見られるように拡大リングを有する円形噴流の 場合には，ノズル出口付近から $u_{c} / u_{m}<1$ になる速度分布とな る. 次に, 図 5 (b) の乱れ強さ分布を見ると, ノズル出口 $\left(x / D_{o}\right.$ =0）ではリング内で増速流となる縮小リングの方が乱れ強度 は小さくなる．拡大リングを有する円形噴流の場合，リング 内周壁面側から生じる乱れが最も強く，下流域で発達し， 徐々に中心軸側へと広がっていく. 外側混合領域では速度分 布と乱れ強さ分布ともに, リング形状による差は見られない. 3.2 リング長さによる影響

図 6 にリング長さが $1 D_{o}$ と $2 D_{o}$ の縮小リングにおける軸方 向速度と軸方向乱れ強さの分布を示す.リング長さが $2 D_{o}$ の 速度は, $0<r / D_{o}<0.25$ においてリング長さが $1 D_{o}$ の場合より も若干大きくなり，その傾向が下流まで続く。これはリング 長さの増加により, リング壁の境界層が厚くなるため増速す ると考えられる. また，乱れ強さ分布を見ると，リング長さ $2 D_{o}$ の方がリング後縁からの乱れが発達し，下流域まで持続 している.

\section{3 偏向角度による影響}

図 7 に偏向角度 $\theta=6^{\circ}, 12^{\circ}$ の縮小リングに执ける軸方向速 度と軸方向乱れ強さの分布を示す. $\theta=12^{\circ}$ の方が, 軸方向速

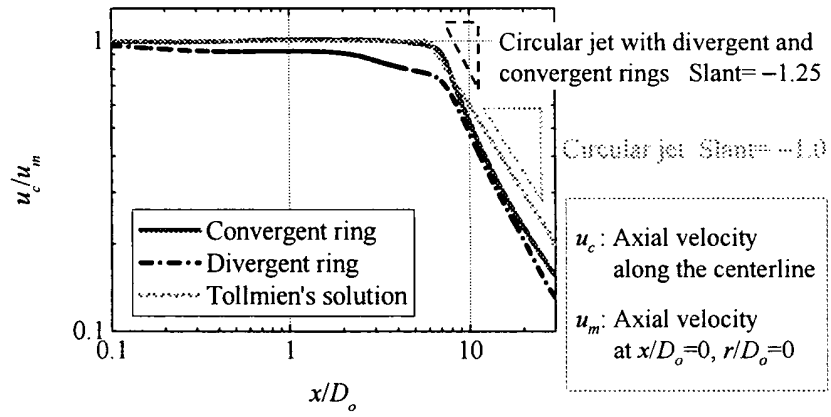

Fig.3 Axial velocity profiles along the centerline of the circular jet with divergent and convergent rings

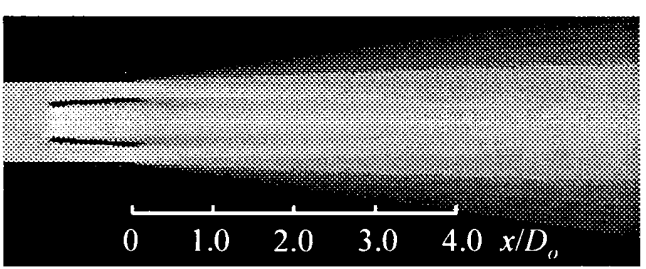

(a) Divergent ring

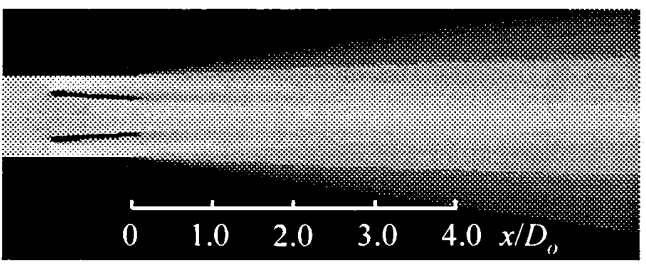

(b) Convergent ring

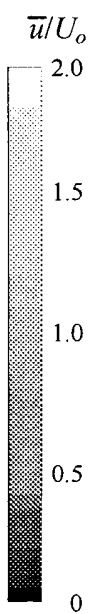

Fig.4 Axial velocity contours of the circular jet with divergent and convergent rings $\left(\theta=6^{\circ}, L=1 D_{o}\right)$
度は噴流中心付近で増加する。.また，乱れ強さは減速側のリ ング内壁からの剥離によって外側環状噴流側で増加し，特に 内側混合領域で乱れの強い領域が下流域まで持続している.

\section{4. 結論}

拡大・縮小リングを有する円形噴流の数值シミュレーショ ンによって以下の結論を得た。

（1）拡大リングを有する円形噴流は，縮小リングを有する円 形噴流に比べて $x / D_{o}<10$ で中心軸上速度は若干低下する。し かし，リングを有する円形噴流はリングを有しない円形噴流 に比べて中心軸上の速度減衰は大きい.

（2）リング長さ $L$ が増加すると，リング壁面の境界層が厚く なることによる速度や乱れの増加が生じる。

（3）偏向角度 $\theta$ が増加すると，噴流中心領域の速度は増加す るが，减速する側のリング壁面からの剥離による乱れ増加が 下流域まで持続する.

\section{参考文献}

1) 千田，西村，羽山，平，機論, B, vol.57 (1991), pp.360-365

2) Tollmien, W., ZAMM, 6 (1926), pp. 468-478

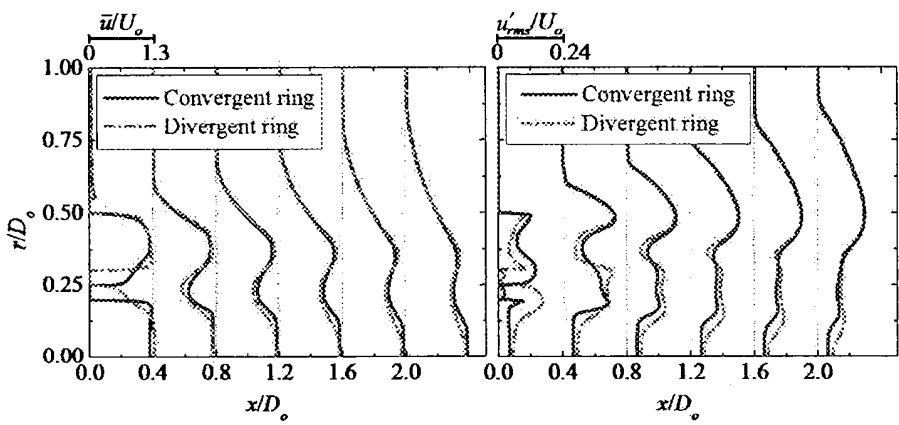

(a) Axial velocity

(b) Turbulent intensity

Fig. 5 Effect of shape of rings $\left(L=1 D_{o}, \theta=6^{\circ}\right)$

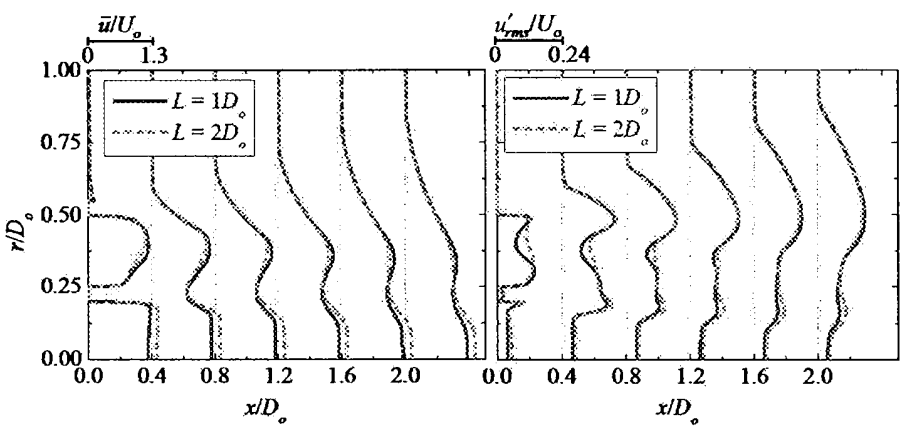

(a) Axial velocity

(b) Turbulent intensity

Fig.6 Effect of length of convergent rings $\left(\theta=6^{\circ}\right)$

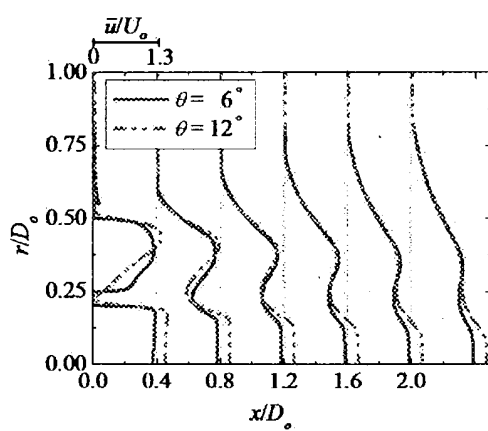

(a) Axial velocity

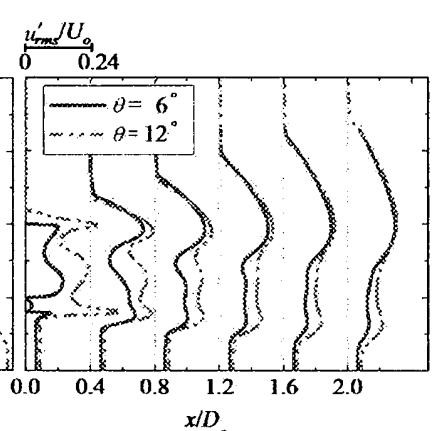

(b) Turbulent intensity
Fig.7 Effect of angle of convergent rings $\left(L=1 D_{o}\right)$ 